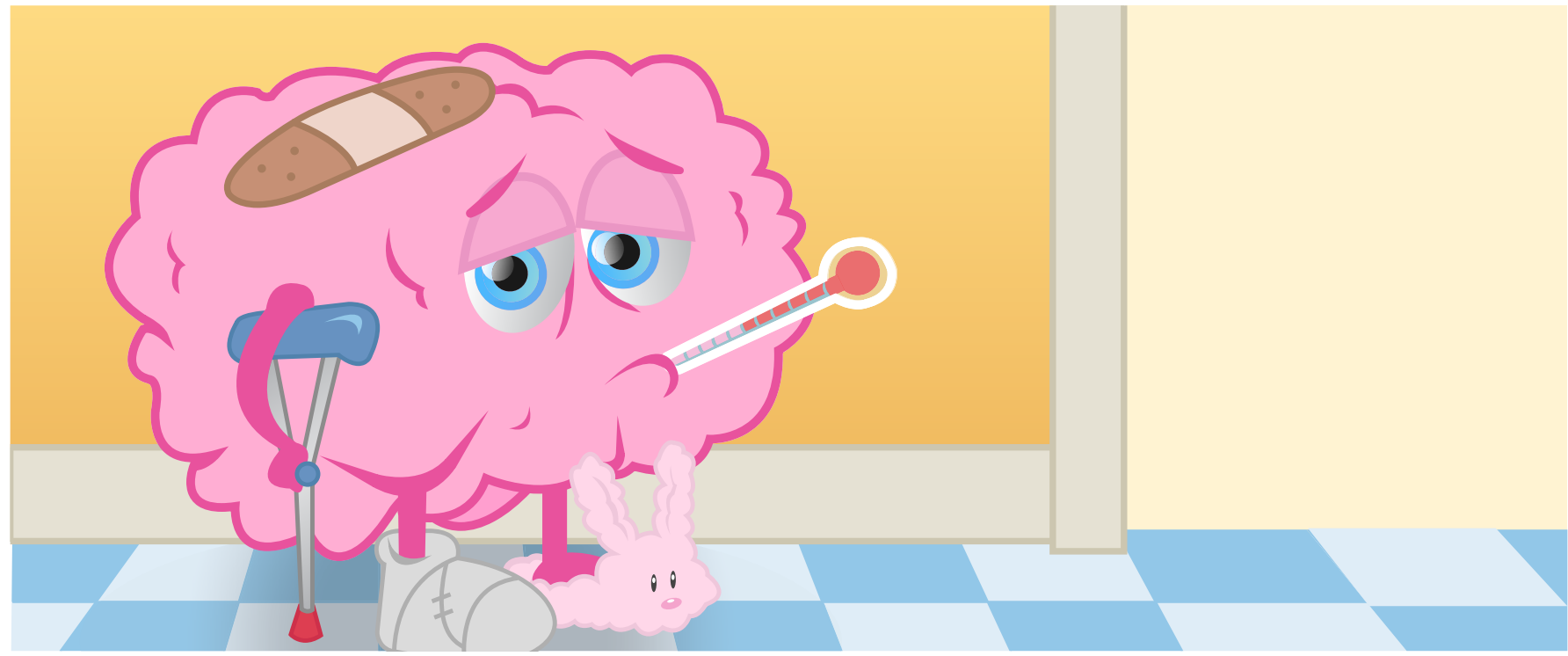

\title{
WHY DOESN'T YOUR BRAIN HEAL LIKE YOUR SKIN?
}

\section{Nina Weishaupt ${ }^{1 *}$ and Angela Zhang $^{2}$ \\ ${ }^{1}$ University of Western Ontario, London, ON, Canada, ${ }^{2}$ McGill University, Montreal, QC, Canada}

\section{REVIEWED BY:}

TRAFALGAR

SCHOOL FOR

GIRLS

12-13 YEARS OLD

\section{SPINAL CORD}

The part of the central nervous system that sits in your spinal column, the bony structure along your back. The spinal cord is mainly responsible for picking up all kinds of feelings from your body and sending it to the brain for processing, as well as for sending movement commands from the brain to your arms and legs.
Skin wounds like scrapes and cuts may be painful, but they usually heal perfectly. Worst case scenario, you may be left with a scar. In contrast, when the brain gets injured, we are often left with disabilities that stay with us for the rest of our lives. What is so different about the brain, and how does it repair itself? Brain cells face unique challenges when they get injured, for example, by a concussion or a stroke. And to cope with these challenges, the brain has an ingenious strategy to deal with injury.

\section{THE BRAIN IS SUPER VULNERABLE}

Your brain and your spinal cord together form what we call the central nervous system. Looking at a skeleton, have you ever asked yourself why the brain and spinal cord are the only organs in our body encased in bone? True, the lungs and the heart are also well protected by the rib cage. But when you look at the skull, it is basically a bony box with a few holes in it to let nerves leave the brain. The nervous system is unique compared to many other organs in that it does not expand or contract like your heart, lungs, and intestines do. Because there is no major movement, it is alright for the central nervous system to be entirely encased in bone. Why is the central nervous system so well protected? The answer is simple: because it is super sensitive and very vulnerable. 
NEURONS

Nerve cells in the brain that receive signals from other nerve cells, process them, and then send along new signals to different nerve cells.

This network of connected neurons is the basis of all the work that the central nervous system performs so you can think, move, and feel things.

\section{CONCUSSION}

A concussion happens when you hit your head hard and your brain bumps against your skull. If you have a bad concussion, you may see stars in front of your eyes, you may not remember what day it is, and you may feel nauseous.

\section{STROKE}

A stroke happens when the blood supply to a brain region is damaged. The nerve cells in that region die off quickly if they stop receiving essential things like sugar and oxygen from the blood.

NEURODEGENERATIVE DISEASES

A disease where neurons die off (or degenerate, which means they die) because they cannot deal with the challenges they face. Most of these challenges are complicated chemical processes.

\section{STEM CELLS}

Immature cells that have not developed into "professional" skin cells, or nerve cells, or any other cells in your body yet.
Which organ of your body do you think you're injuring most often? Probably, your skin. Think about a time when you fell, your skin broke open and you had a wound like a scrape or a cut for some time. If this injury happened a while ago, chances are you won't even see the spot on your skin any more. Or maybe you can see a scar, but basically your skin was able to repair itself almost perfectly. Unfortunately, the brain and spinal cord are fundamentally different. If your brain gets injured, some damage may persist throughout the rest of your life.

\section{WHY CAN'T THE BRAIN REPAIR ITSELF LIKE YOUR SKIN CAN?}

\section{NERVE CELLS DO NOT RENEW THEMSELVES}

Your skin cells keep dividing, they die and give birth to new cells all the time, even when you're not injured. After an injury, the skin makes a bunch of new cells and uses them to heal your wound. Yet, nerve cells in your brain, also called neurons, do not renew themselves. They do not divide at all. There are very few exceptions to this rule - only two special places in the brain can give birth to new neurons. For the most part though, the brain cannot replenish dead neurons. This is especially worrisome because neurons are very sensitive cells and they die for all sorts of reasons. When you bump your head and suffer a concussion, neurons die. When there is a glitch in the blood supply to the brain, also called a stroke, neurons die. Neurons also die when faced with changes in their own functions, which happens in the so-called neurodegenerative diseases like Parkinson's disease and Alzheimer's disease.

Here is the good news. Because loss of neurons is usually permanent, scientists are working on two important strategies to help the brain after injury. One way is to protect the nervous system immediately after the damage occurs. This damage could be a stroke, a severe concussion, or any kind of injury. If we can somehow limit the number of neurons that die early after injury, then we are keeping the damage to a minimum. To help with repair later on after the injury, after the damage is done, some scientists are trying to use stem cells as a treatment for neuronal loss in the brain. ${ }^{1}$ These stem cells are young and immature cells that have not developed into "professional" cells yet. They have the capacity to develop into brand new neurons if scientists treat them with special molecules. This is a little like elementary school students who are not doctors or plumbers yet, but they have the capacity to become any professional in the future, given the right training. The biggest challenge with replacing dead neurons with stem cells is to have these newcomer neurons integrate, or fit into, the existing brain networks the right way. The new neurons can't just hang out in the brain, we need

\footnotetext{
${ }^{1}$ http://www.eurostemcell.org/commentanalysis/stem-cell-therapies-and-neurological-disordersbrain-what-truth
} 
STEM CELLS

\section{(CONTINUED)}

They have the capacity to develop into any cell in your body, and their future "profession" is determined by what molecules they encounter as they mature. They can develop into any professional cell, including neurons, when scientists treat them with specific molecules.

\section{MYELIN SHEATH}

A fatty covering that envelops axons to make signals travel along axons as fast as possible. For example, this sheath is what allows you to react quickly when you hurt yourself, such as pulling back your hand from touching a hot stove top.

\section{FIGURE 1}

Left: the structure of a brain cell. Note the branch-like arms that extend from the cell body (top left corner). These arms receive incoming signals. The really long arm that extends to the bottom right is called the axon, which sends signals to a receiving cell. The axon is enveloped by a myelin sheath (in darker violet), which helps signals travel faster along the axon to the receiving cell. Right: when an axon gets injured, the end part dies off and leaves an axon stump. Stumps have a hard time to grow back after injury. them to form connections with other cells and do the job that all neurons do: process signals.

\section{NERVE CELLS HAVE TROUBLE REGROWING \\ DAMAGED PARTS}

Looking at the structure of a neuron, you will notice it has a cell body and several arms that it uses to connect and talk with other neurons (Figure 1, left). The really long arm that sends signals to other neurons is called axon, and axons can be really long. If an axon is damaged along its way to another cell, the damaged part of the axon will die (Figure 1, right), while the neuron itself may survive with a stump for an arm. The problem is neurons in the central nervous system have a hard time regrowing axons from stumps. Why do skin cells not have this problem? Skin cells are much simpler in structure. And because they can give birth to entirely new cells, they don't face the problem of having to repair parts of their cells.

So, why do damaged neurons have trouble regrowing axons?

First, they need motivation. There are special molecules that help activate growth in neurons. More of these motivating molecules are made when the neurons are active. So, if you keep your brain active, your neurons are more likely to grow. This is true both after injury and in the healthy brain.

Second, axons face a hostile environment that is full of molecular "stop signs" that signal "no trespassing" to axons. Some stop signs are part of the sheath, or covering, around neighboring axons, called myelin sheath (Figure 1, left). Some stop signs are part of a scar that gets built like a protective wall around an injury in an effort to keep the damage from spreading. These

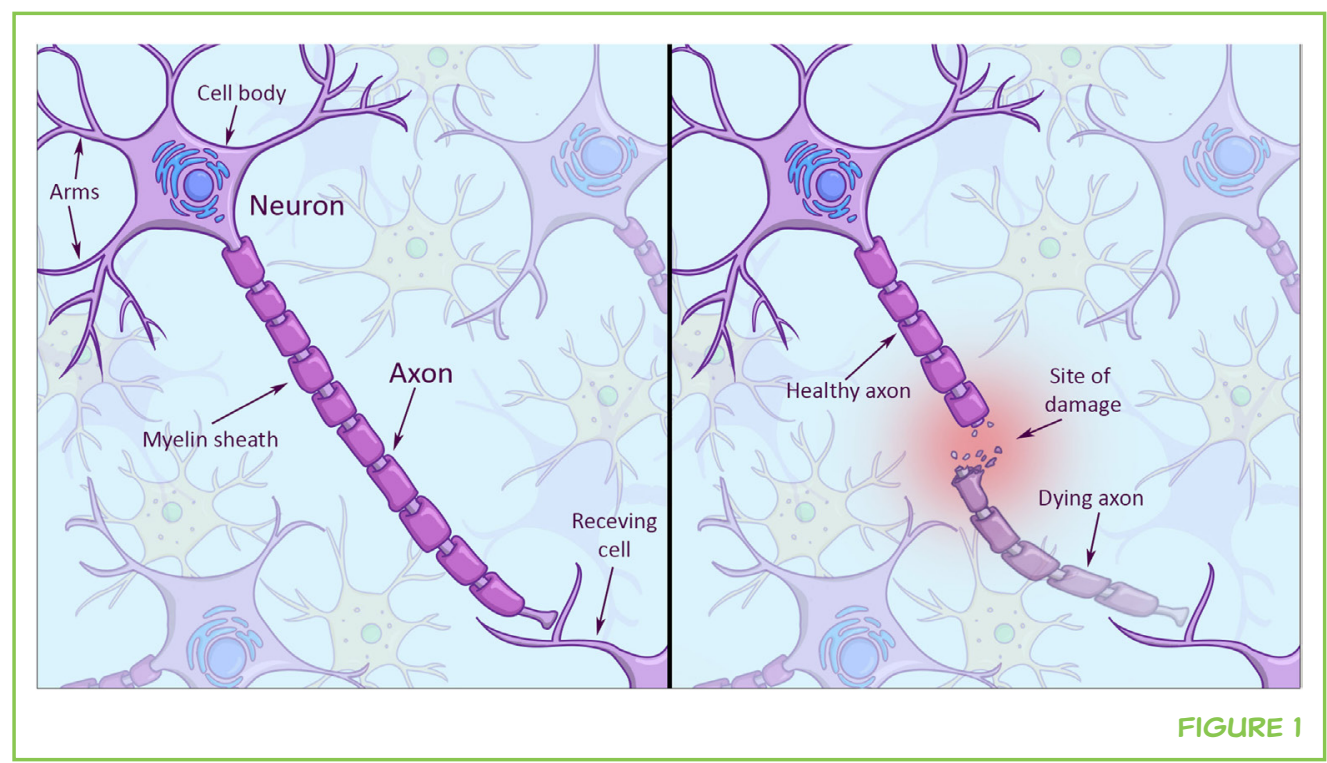




\section{FIGURE 2}

Growing axons (green in top right and bottom left corners) looking for new target cells to connect with have a hard time in an injury environment. This is partly due to starshaped support cells (astrocytes, in yellow), which spit out chemicals (red). These chemicals stop axon growth.

\section{ASTROCYTES}

Translates into "star cells," due to the star-like shape of these cells. Astrocytes are support cells in the brain that are very different from neurons. They support neurons in many ways, such as by keeping harmful molecules away.

\section{IMMUNE}

\section{RESPONSE}

Your body's reaction to injury. The immune response will send out specialized cells, some from the region of injury and some from the blood stream, to help clean up and repair.

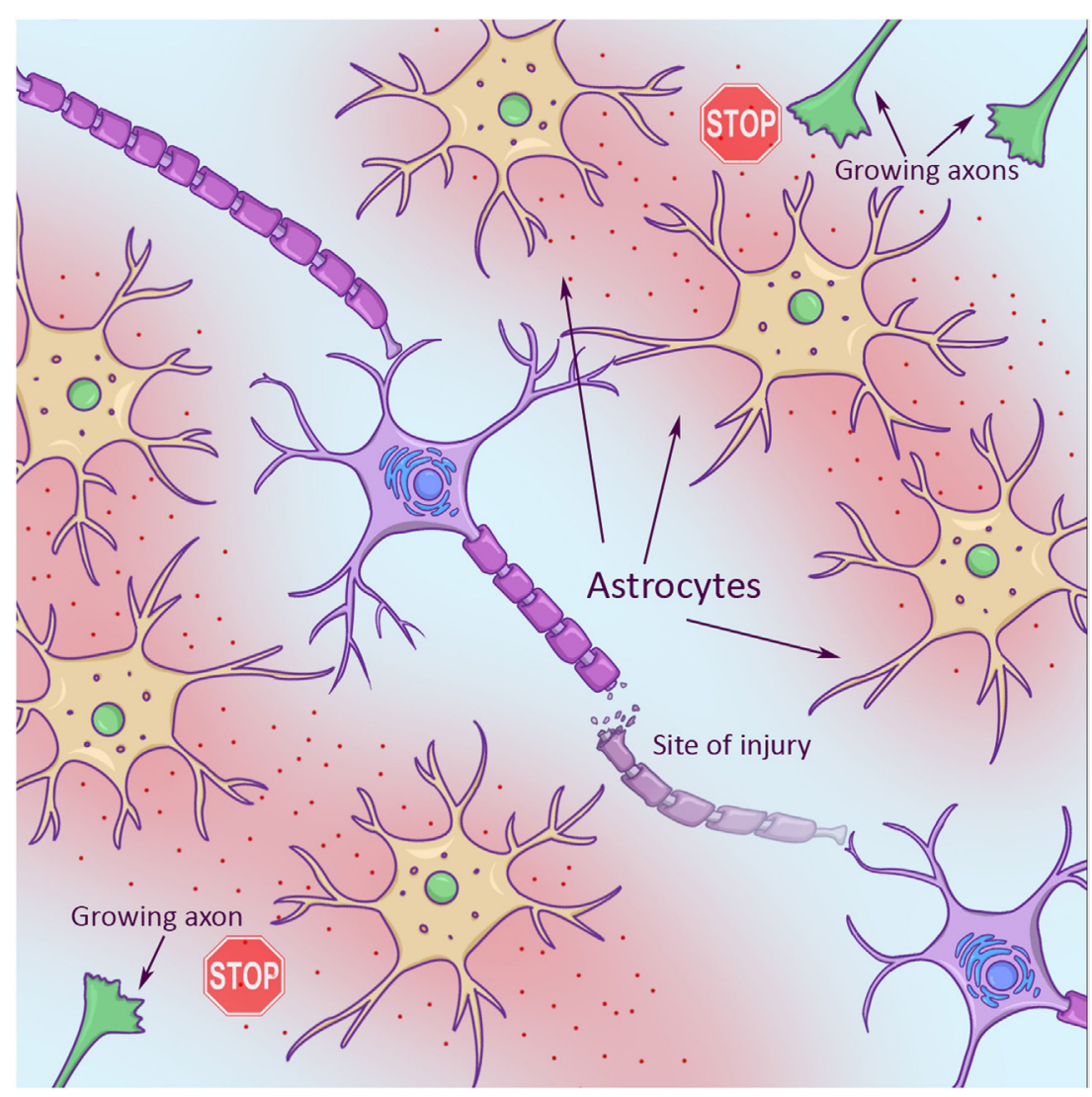

FIGURE 2

scars are made by brain cells called astrocytes (star cells, due to their starlike appearance). Scar-building astrocytes are just trying to help, but they also release a chemical into their environment that makes it hard for axons to grow (Figure 2).

But, there is good news here as well. Scientists are working on strategies to motivate injured neurons to grow by using special growth molecules and to eliminate stop signs for axons in order to make the injury environment more supportive for nerve cell growth [1].

\section{THE IMMUNE RESPONSE IN THE BRAIN IS DIFFERENT FROM THAT IN SKIN}

The immune response plays an essential role in any kind of repair after injury. In injured skin, immune cells will rush to the site of injury from the blood and help the resident immune cells clean up debris from dead cells. Once the clean up is done, the immune cells die and stop the fight. The brain has specialized resident immune cells as well, and they will become activated when they sense danger or damage. A common problem in the brain is that the activated immune cells often don't know when to stop fighting. If they continue to spit out toxic chemicals over long periods, they can cause more harm than good, by killing healthy neurons. This is why scientists are trying to understand what switches brain immune cells on and off and trying to 


\section{PLASTICITY}

The ability of nerve cells to change their connections to other nerve cells. Plasticity is the process of neurons building new arms to connect with other neurons, or simply weakening or strengthening an existing connection with another nerve cell.

\section{FIGURE 3}

In response to an injury, a brain cell can adapt by growing new arms (axon branch with green

background) and also by increasing or decreasing the strength of existing connections (connection between axon and receiving cell with green background in bottom right). figure out how they can modify the response of these immune cells, so the cells can be helpful rather than harmful [2].

\section{HOW THEN DOES THE BRAIN REPAIR ITSELF?}

Learning about the limitations of neurons compared to skin cells, you may be disappointed that an organ as important as the brain seems to be unprepared for damaging events. The truth is, the central nervous system has an ingenious strategy to repair itself that is entirely different from the strategy used by other organs. The brain will never be the same as before the damage, but it will try to compensate for its losses. Neurons in the brain are able to change their connections with each other. This process is called plasticity, and it helps the brain to adapt to the loss of neurons. Forget for a moment about dying cells, the responsibility for plasticity lies entirely with the surviving cells. How does this work?

Because a neuron's primary job is to send out a signal, neurons are super good at sensing "free real estate", or other neurons, that they can connect with. Apart from growing new arms to connect with new cells, neurons can also modify the strength of existing connections with other neurons (Figure 3). They can either strengthen such connections or they can weaken them, resulting in a totally new network of connections in the brain. This

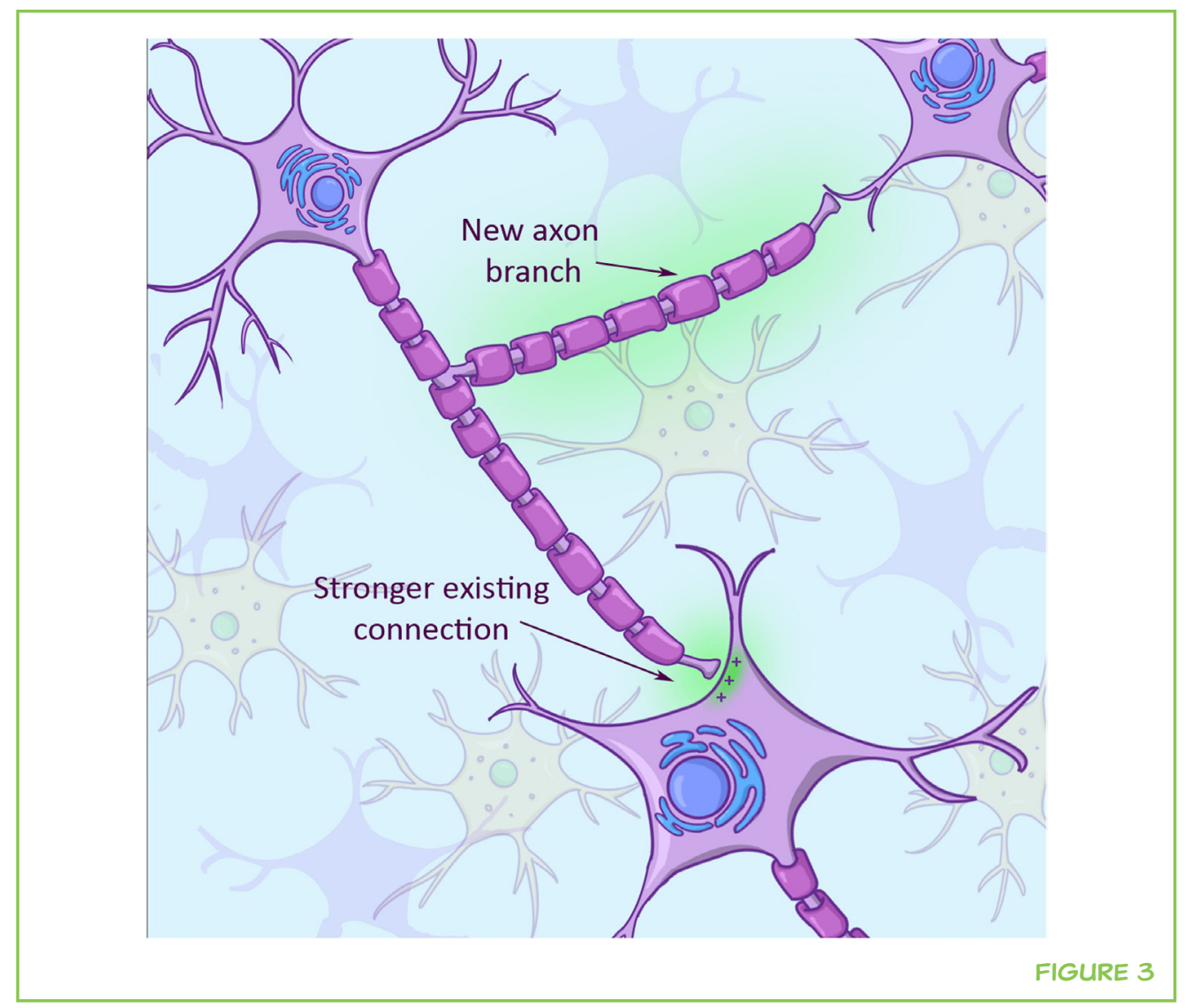


plasticity is driven and directed by activities that we perform. After a stroke or brain injury, patients usually improve to a certain extent doing some sort of physical therapy. The improvement is not so much due to growth of new neurons, as you learned above, but because these patients keep stimulating plasticity and, therefore, build new connections between surviving neurons in their brains!

Unfortunately, plasticity as a repair mechanism has its limits. Plasticity relies entirely on surviving cells, so the more surviving cells there are, the better. If someone suffers a severe brain injury, or a huge stroke that kills a substantial amount of brain cells, then there are less surviving neurons available for plasticity than following a mild concussion. The more cells available for plasticity to work with, the more plasticity can occur. This is why severe central nervous system injuries usually result in lasting disabilities. And because the consequences of these severe injuries are so dire, scientists are working hard to try to protect neurons from dying, to replace lost cells with stem cells, to help injured neurons grow, and to stimulate plasticity.

\section{REFERENCES}

1. Silver, J., Schwab, M. E., and Popovich, P. G. 2015. Central nervous system regenerative failure: role of oligodendrocytes, astrocytes, and microglia. Cold Spring Harb. Perspect. Biol. 7(3):a020602. doi:10.1101/cshperspect.a020602

2. Loane, D. J., and Kumar, A. 2015. Microglia in the TBI brain: the good, the bad, and the dysregulated. Exp. Neurol. 275(Pt 3):316-27. doi:10.1016/j.expneurol. 2015.08.018

SUBMITTED: 16 February 2016; ACCEPTED: 12 September 2016; PUBLISHED ONLINE: 26 September 2016.

EDITED BY: Lesley K. Fellows, McGill University, Canada

CITATION: Weishaupt N and Zhang A (2016) Why Doesn't Your Brain Heal Like Your Skin? Front. Young Minds 4:22. doi:10.3389/frym.2016.00022

CONFLICT OF INTEREST STATEMENT: The authors declare that the research was conducted in the absence of any commercial or financial relationships that could be construed as a potential conflict of interest.

COPYRIGHT $\odot 2016$ Weishaupt and Zhang. This is an open-access article distributed under the terms of the Creative Commons Attribution License (CC BY). The use, distribution and reproduction in other forums is permitted, provided the original author(s) or licensor are credited and that the original publication in this journal is cited, in accordance with accepted academic practice. No use, distribution or reproduction is permitted which does not comply with these terms. 


\section{REVIEWED BY}

\section{TRAFALGAR SCHOOL FOR GIRLS, 12-13 YEARS OLD}

Seventeen young girls from Grade 7 participated in this review. Some of them are athletes and one of them had a concussion before. Some of them have family members/friends with mental illnesses. This group was very enthusiastic about the review process and everyone in the class participated and gave valuable feedbacks. Special mention to their science teacher Christianne Loupelle for being very motivating and considerate during the review process.

\section{AUTHORS}

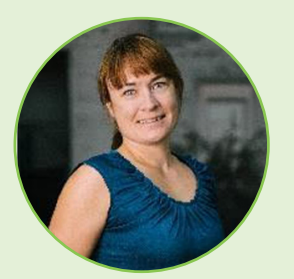

\section{NINA WEISHAUPT}

I am a neuroscientist with experience in spinal cord injury, stroke, and Alzheimer's disease research. I am interested in furthering our understanding of central nervous system plasticity, inflammation, and membrane lipids as targets for novel therapies. *nweishau@uwo.ca

\section{ANGELA ZHANG}

I am currently a masters' student at McGill University. In the past, I studied how distant parts of the brain are affected by stroke in another part of the brain. Now, I am interested in studying traumatic brain injury (concussion) and how the brain's visual system recovers afterward. Apart from research, I love travelling, playing piano, drawing, and skiing. 